\title{
KEPEMIMPINAN SOSIAL DALAM PENDIDIKAN
}

\author{
Imam Taulabi*
}

\begin{abstract}
Abstrak
Kepemipinan sosial menjadi kebutuhan dasar dalam dunia lembaga. Keberadaan pemimpin dalam lembaga-lembaga sosial sangat menentukan dalam perencanaan, pengembangan dan pelaksanaan serta kemajuan sebuah lembaga sosial. Keberadaan pemimpin sebagai figur, sangat menetukan keberhasilan sebuah lembaga. Ada banyak contoh yang dapat dijadikan tolak ukur atas keberhasilan kepemipinan sosial. Kepemimpinan tidak lepas dari latar belakang pendidikan yang pernah ditempuh oleh seseorang. Seorang pemimpian harus memiliki kemampuan dasar sebagai syarat minimal. Dari sini akan membentuk tipologi kepemimpinan sosial yang berbeda.
\end{abstract}

Kata Kunci: Kepemimpinan, Sosial, Pendidikan

\section{Pendahuluan}

Kepemimpinan, menurut Baron dan Greenberg adalah suatu proses dimana seorang individu mempengaruhi kelompok lain untuk mencapai tujuan organisasi. Sedang menurut Newell, kepemimpinan merupakan suatu proses melalui individuindividu atau kelompok-kelompok yang secara sengaja mempengaruhi yang lain dalam pengembangan dan pencapaian tujuan kelompok organisai. Lain halnya dengan Gatesood mendefinisikan kepemimpinan sebagai proses mempengaruhi kegiatan-kegiatan individu atau kelompok untuk mencapai suatu tujuan. ${ }^{1}$

* Institut Agama Islam Tribakti (IAIT) Kediri DPK STAIN Kediri

1 A. Habibullah, ed., Kepemimpinan Sekolah Mandiri, (Jakarta: Puslitbang Depag, 2005), h. 1. 
Dari pendapat beberapa ahli di atas dapat dipahami bahwa kepemimpinan adalah proses dan aktivitas sekumpulan kemampuan seseorang, untuk dijadikan sarana dalam rangka meyakinkan orang yang dipimpinnya agar mereka mau dan dapat melaksanakan tugas-tugas yang dibebankan kepadanya. Atau bila dikaitkan dengan pengambilan keputusan, kepemimpinan diartikan sebagai kemampuan dan keterampilan seseorang yang menduduki jabatan sebagai pimpinan satuan kerja untuk mempengaruhi perilaku orang lain, terutama bawahannya, untuk berpikir dan bertindak sedemikian rupa sehingga melalui perilaku yang positif. Ia memberikan sumbangsih nyata dalam pencapaian tujuan organisasi. ${ }^{2}$

Sehubungan dengan definisi di atas, maka pemimpin suatu lembaga pendidikan mempunyai kewenangan untuk memajukan atau meningkatkan mutu bawahannya. Dalam hal ini adalah masalah mutu pendidikan Islam.

Perbedaan pendapat ini tentunya muncul sebagai akibat dari adanya perbedaan standar, perbedaan kriterium dalam menilai sistem pendidikan kita. Apa ukuran yang harus kita pergunakan untuk menentukan tinggi rendahnya mutu pendidikan? Perlu diingat dalam hubungan ini, bahwa di dunia pendidikan, termasuk pendidikan Islam tidak hanya satu ukuran kebaikan. Untuk setiap situasi pendidikan selalu terdapat lebih dari satu jenis kebaikan. ${ }^{3}$

\section{Pendidikan Sebagai Modal \\ Pendidikan Sebagai Modal Individu}

Pendidikan merupakan suatu usaha atau proses yang dilakukan secara sadar oleh seseorang agar mereka dapat mencapai kedewasaan. Dalam pengertian yang sederhana dan umum, makna pendidikan adalah usaha manusia untuk menumbuhkan dan mengembangkan potensi-potensi pembawaan baik jasmani maupun rohani sesuai dengan nilai-

2 Sondang P. Siagian, Organisasi, Kepemimpinan dan Prilaku Organisasi, (Jakarta: CV Hani Masagung, 1994), h. 24.

${ }^{3}$ Mochtar Buchori. Ilmu pendidikan dan Praktek Pendidikan dalam Renungan, (Yogyakarta: Tiara Wacana, 1994), h. 34. 
nilai yang ada dalam masyarakat dan kebudayaan. ${ }^{4}$ Ada beberapa konsep pendidikan sebagai modal pengembangan jatidiri individu sebagaimana dikemukakan oleh para ahli.

Tim Dosen IKIP Malang menyimpulkan pengertian pendidikan sebagai:

a. Aktivitas dan usaha manusia untuk meningkatkan kepribadiannya dengan jalan membina potensi-potensi pribadinya yaitu rohani (fikir, karsa, rasa, cipta dan budi nurani) dan jasmani (panca indra serta keterampilanketerampilan).

b. Lembaga yang bertanggung jawab menetapkan cita-cita (tujuan) pendidikan, isi, sistem dan organisasi pendidikan. Lembaga-lembaga ini meliputi: keluarga, sekolah dan masyarakat (negara).

c. Hasil atau prestasi yang dicapai oleh perkembangan manusia dan usaha lembaga-lembaga tersebut dalam mencapai tujuannya.

Selanjutnya sebagaimana yang dikutip oleh Djumberansyah Indar dalam bukunya Freeman Butt yang berjudul Cultural History of Western Education, bahwa:

a. Pendidikan adalah kegiatan menerima dan memberikan pengetahuan sehingga kebudayaan dapat diteruskan dari generasi ke generasi berikutnya.

b. Pendidikan adalah suatu proses. Melalui proses ini individu diajarkan kesetiaan dan kesediaan untuk mengikuti aturan. Melalui cara ini pikiran manusia dilatih dan kembangkan.

c. Pendidikan adalah suatu proses pertumbuhan. Dalam proses ini individu dibantu pengembangan kekuatan, bakat, kesanggupan dan minatnya.

d. Pendidikan adalah rekontruksi dan reorganisasi pengalaman yang menambah arti serta yang menambah kesanggupan untuk memberikan arah bagi pengalaman selanjutnya.

e. Pendidikan adalah suatu proses. Melalui proses ini seseorang menyesuaikan diri dengan unsur-unsur pengalamannya yang menjadi kepribadian modern sehingga

${ }^{4}$ Indar Djumberansyah, Filsafat Pendidikan, (Surabaya: Abditama, 1994), h. 16. 
dapat mempersiapkan diri bagi kehidupan masa dewasa yang berhasil. ${ }^{5}$

Berdasarkan beberapa pengertian pendidikan tadi, maka terdapat beberapa ciri atau unsur umum dalam pendidikan sebagai modal individu yang dapat disimpulkan sebagai berikut:

a. Pendidikan mengandung tujuan yang ingin dicapai, yaitu individu yang kemampuan-kemampuan dirinya berkembang sehingga bermanfaat untuk kepentingan hidupnya sebagai seorang individu, maupun sebagai warga negara atau warga masyarakat.

b. Untuk mencapai tujuan tersebut, pendidikan perlu melakukan usaha yang disengaja dan terencana untuk memilih isi (bahan materi), strategi kegiatan, dan teknik penilaian yang sesuai.

c. Kegiatan tersebut dapat diberikan dilingkungan keluarga, sekolah dan masyarakat berupa pendidikan jalur sekolah (formal), dan pendidikan jalur luar sekolah (informal dan non formal). Oleh karenanya tidaklah dapat dibenarkan pertanggungjawaban suatu tindakan atau usaha yang berpijak pada landasan yang dicari-cari alasannya untuk kepentingan diri atau golongan. ${ }^{6}$

\section{Pendidikan Sebagai Modal Prinsip Individu}

Adapun dasar pendidikan sebagai modal prinsip individu dapat ditinjau dari beberapa segi, setidaknya memiliki beberapa sandaran dasar yang di antaranya:

a. Dasar dari segi yuridis atau hukum adalah dasar-dasar pelaksanaan agama yang berasal dari peraturan perundangundangan, baik langsung maupun tidak langsung yang mana hal ini dapat dijadikan pegangan dalam pelaksanaan pendidikan baik di lembaga formal maupun non formal.

b. Dasar religius yaitu dasar yang berdasarkan dari ajaran agama Islam yang tertera dalam ayat al-Quran dan AlHadits menurut ajaran agama Islam bahwa pelaksanaan pendidikan adalah wajib.

\footnotetext{
${ }^{5}$ Ibid, h. 19-20.
}

6 Abu Ahmadi, Nur Uhbiyati, Ilmu Pendidikan, (Jakarta: Rineka Cipta, 1991), h. 190. 
c. Dasar sosial psikologi yaitu manusia membutuhkan suatu pegangan hidup yaitu agama, dan dalam kenyataannya agama merupakan bagian yang tidak dapat dipisahkan dari kehidupan bangsa Indonesia. Dan pada hakekatnya masyarakat akan merasa aman, tenang, dan tentram hatinya apabila bisa mendekatkan dirinya kepada Tuhannya. ${ }^{7}$

Selanjutnya motivasi utama guna menuju proses pendidikan yang ideal individu sebagaimana dikutip oleh $\mathrm{M}$. Ngalim Purwanto dalam bukunya Langeveld yang berjudul Beknopte Theoretische Paedagogiek, mengutarakan macammacam tujuan pendidikan sebagai berikut: Pendidikan, dari segi kehidupan kultur umat manusia tidak lain adalah sebagai salah satu alat pembudayaan masyarakat manusia itu sendiri. Sebagai suatu alat pendidikan dapat difungsikan untuk mengarahkan perkembangan dan pertumbuhan hidup manusia. Sebagai makhluk pribadi dan juga makhluk sosial kepada titik optimal kemampuan untuk memperoleh kesejahteraan hidup dunia maupun akhirat. Untuk itulah maka pendidikan harus benarbenar memiliki kualitas bagi manusia.

\section{Kepemimpinan Sosial}

Istilah kepemimpinan sosial dalam kaitanya dengan pendidikan, setidaknya mengandung dua pengertian. Dimana kata "pendidikan" menerangkan dalam lapangan apa dan dimana kepemimpinan itu berlangsung, dan sekaligus menjelaskan pula sifat atau ciri-ciri bagaimana yang harus terdapat atau dimiliki oleh kepemimpinan tersebut.

Pengertian "Kepemimpinan" itu bersifat universal, berlaku dan terdapat pada berbagai bidang kegiatan hidup manusia. Oleh karena itu, sebelum dibahas pengertian kepemimpinan yang menjurus akibat pendidikan, maka perlu dipahami dahulu pengertian kepemimpinan yang bersifat sosial dan universal. Dalam hal ini banyak sekali para ahli yang berusaha memberikan definisi kepemimpinan, di antaranya:

1. Menurut Dirawat, Busro Lamberi, Soekarto Indra Fachrudi dalam bukunya "Pengantar Kepemimpinan Pendidikan"

7 Zuhairini et.al, Metodologi Pendidikan Agama Islam, (Solo: Ramadhani, 1983), h. 31. 
bahwa: kepemimpinan adalah kemampuan dan kesiapan yang dimiliki oleh seseorang untuk dapat mempengaruhi, mendorong, mengajak, menuntun, menggerakkan dan kalau perlu memaksa orang lain, agar ia menerima pengaruh itu dan selanjutnya berbuat sesuatu yang dapat membantu pencapaian sesuatu maksud atau tujuan-tujuan tertentu. ${ }^{8}$

2. Menurut Hadari Nawawi dalam bukunya "Administrasi Pendidikan", bahwa: kepemimpinan berarti kemampuan menggerakkan memberikan motivasi dan mempengaruhi orang-orang agar bersedia melakukan tindakan-tindakan yang terarah pada pencapaian tujuan melalui keberanian mengambil keputusan tentang kegiatan yang harus dilakukan. ${ }^{9}$

3. Menurut Burhanuddin dalam bukunya "Analisis Administrasi Manajemen dan Kepemimpinan Pendidikan", bahwa: kepemimpinan adalah usaha yang dilakukan oleh seseorang dengan segenap kemampuan yang dimilikinya untuk mempengaruhi, mendorong, mengarahkan dan menggerakkan individu-individu supaya mereka mau bekerja dengan penuh semangat dan kepercayaan dalam mencapai tujuan-tujuan organisasi. ${ }^{10}$

Dari ketiga definisi di atas, dapat disimpulkan bahwa kepemimpinan adalah proses kegiatan seseorang yang memiliki kemampuan untuk mempengaruhi, mendorong, mengarahkan, dan menggerakkan individu-individu supaya timbul kerjasama secara teratur dalam upaya mencapai tujuan yang telah ditetapkan bersama. Sedangkan pengertian pendidikan itu sendiri, sebagaimana yang dikatakan oleh Burhanuddin dalam bukunya "Analisis Administrasi Manajemen dan Kepemimpinan Pendidikan", bahwa:

Apabila pengertian kepemimpinan dipadukan dengan pengertian pendidikan, maka akan muncul pengertian Kepemimpinan sosial secara fenomenologi banyak memiliki hubungan yang sangat

8 Dirawat, Busro Lamberi, Soekarto Indra Fachrudi, Pengantar Kepemimpinan Pendidikan, (Surabaya: Usaha Nasional, 1983), h. 23.

Hadari Nawawi, Administrasi Pandidikan, (Jakarta: CV Haji Masagung, 1998), h. 81.

Burhanuddin, Analisis Administrasi Manajemen dan Kepemimpinan Pendidikan, (Jakarta: Bumi Aksara, 1994), h. 63. 
erat kaitanya denan latar belakang pendidikan sebagai satu kemampuan dan proses mempengaruhi, mengkoordinir, dan menggerakkan orang lain yang ada hubungan dengan pengembangan ilmu pendidikan dan pelaksanaan pendidikan dan pengajaran, agar kegiatan-kegiatan yang dijalankan secara sosiologis dapat lebih efisien dan efektif didalam pencapaian tujuan-tujuan pendidikan dan pengajaran bagi orang lain secara sistemik dan sustinable. ${ }^{11}$

Dari pengertian di atas, setidaknya dapat diketahui beberapa unsur pokok, diantaranya: (1) Tujuan kepemimpinan, (2) Individu yang mempengaruhi kelompok/ organisasi/ lembaga, (3) Individu yang dipengaruhi, dikoordinasi, digerakkan, (4) Proses interaksi antara pemimpin dan yang dipimpin dalam rangka mempengaruhi. Mengkoordinasikan dan menggerakkan, dan Situasi berlangsungnya kepemimpinan yang dilakukan.

\section{Syarat Minimal Kepribadian Pemimpinan Sosial}

Sebagai seseorang pemimpin, tentu saja diharapkan memiliki kelebihan-kelebihan daripada orang yang dipimpinnya. Oleh karenanya; pemimpin sosial, setidaknya nantinya selalu berhadapan dengan orang lain dalam konteks sosial, maka ia harus memiliki syarat kepribadian tertentu. Syarat-syarat tersebut antara lain sebagaimana yang dikemukakan oleh Hadari Nawawi di bawah ini:

a. Memiliki kecerdasan atau intelegensi yang cukup baik. Keputusan yang tepat dalam mewujudkan beban tugas organisasinya. Di samping itu, pemimpin sosial harus mampu membantu anggota kelompoknya mengatasi kesulitan yang timbul, sehingga selalu dibutuhkan kelompoknya bilamana menghadapi masalah.

b. Percaya diri dan bersifat membership. Seorang pemimpin harus selalu yakin bahwa dengan kemampuan yang dimilikinya, setiap beban kerjanya akan dapat diwujudkan. Keyakinan akan kemampuan yang dimiliki itu tidak berarti seorang pemimpin harus bekerja sendiri. Akan tetapi pemimpin harus mampu menjalin kerjasama dengan orang

11 Hendyat Soetopo dan Wasty Soemanto, Kepemimpinan dan Supervisi Pendidikan, (Jakarta: Bina Aksara, 1984), h. 4. 
lain di dalam kelompoknya. Menyakinkan anggota kelompoknya mengenai keputusannya adalah sesuatu yang terbaik untuk dilaksanakan, dengan berpegang kepada prinsip mengutamakan kepentingan kelompok dan dengan berlandaskan pada kebenaran.

c. Cakap bergaul dan ramah tamah. Pemimpin yang memiliki kemampuan bergaul akan mampu pula menghayati dan memahami sikap, tingkah laku, kebutuhan, kekecewaan yang timbul, harapan-harapan dan tuntutan-tuntutan anggota kelompoknya. Yang mana hal tersebut harus dibina melalui sikap yang ramah dan hormat menghormati dengan anggota kelompok walau pun kedudukannya sekedar seorang pesuruh.

d. Kreatif, penuh inisiatif dan memiliki hasrat/kemauan untuk maju dan berkembang menjadi lebih baik. Seorang pemimpin harus mampu memprakarsai suatu kegiatan secara kreatif. Selalu terdorong untuk memunculkan inisiatif baru dalam rangka mewujudkan beban kerja, sebagai pencerminan kemauannya untuk bekerja secara efektif.

e. Organisatoris yang berpengaruh dan berwibawa. Seorang pemimpin harus mampu mengelola kerjasama sekelompok manusia sebagai suatu organisasi, dalam pembagian suatu kerja dan penempatan personal secara tepat dan berdaya guna serta memiliki kemampuan mempengaruhi orang lain dalam hubungan manusiawi yang diliputi situasi kewibawaan.

f. Memiliki keahlian atau keterampilan dalam bidangnya. Pemimpin yang memiliki pengetahuan dan pengalaman yang cukup di bidangnya, akan mampu melihat ke depan dalam meningkatkan perkembangan organisasi/lembaga yang dipimpinnya.

g. Suka menolong, memberi petunjuk dapat menghukum secara konsekuen dan bijaksana. Seorang pemimpin harus selalu berusaha membantu orang-orang yang dipimpinnya apabila menghadapi kesulitan, baik itu dalam bidang kerja maupun pribadi. Di samping itu pemimpin harus bersifat tegas dan konsekuen dalam mengatasi kekeliruan, kesalahan dan penyalahgunaan wewenang dari kalangan anggotanya. 
h. Memiliki keseimbangan/kestabilan emosional dan bersifat sabra. Seorang pemimpin harus mampu mengendalikan emosinya dan selalu menggunakan pemikiran yang rasional dan logis dalam menghadapi masalah dan dalam mengambil keputusan, untuk itu seorang pemimpin harus bersifat sabar, teliti dan hati-hati dalam memutuskan tindakan-tindakan yang akan dilaksanakan.

i. Memiliki semangat pengabdian dan kesetiaan yang tinggi. Pemimpin yang baik adalah yang selalu setia pada cita-cita organisasi yang dipimpinnya. Pengabdian lebih diutamakan daripada kepentingan pribadi, sehingga tampak kesediaan berkorban dalam tingkah lakunya demi kepentingan organisasinya.

j. Berani mengambil keputusan dan bertanggungjawab. Seorang pemimpin harus berani dalam mengambil keputusan sehingga kegiatan tidak tertunda-tunda dan setiap personal dapat mewujudkannya dengan cara dan waktu yang tepat. Disamping itu, pemimpin dituntut mampu bertanggungjawab atas segala akibat dari keputusan yang telah dibuatnya.

k. Jujur, rendah hati, sederhana dan dapat dipercaya. Kejujuran, rendah hati, sederhana dan dapat dipercaya harus menjiwai dan tercermin dalam setiap gerak dan tingkah laku yang wajar.

1. Bijaksana dan selalu berlaku adil. Seorang pemimpin harus bijaksana dan adil dalam membagi pekerjaan dan dalam menyelesaikan masalah-masalah yang berkenaan dengan perorangan atau kelompok-kelompok kecil di dalam organisasi. Dengan kata lain, seorang pemimpin harus mampu mengambil keputusan secara wajar dan tepat walaupun berbeda antara satu dengan yang lainnya.

m. Disiplin, seorang pemimpin harus berusaha dengan sungguh-sungguh dalam menegakkan disiplin kerja, disiplin waktu dan dalam mentaati peraturan-peraturan yang telah ditetapkan di dalam organisasi yang dipimpinnya.

n. Berpengetahuan dan berpandangan luas. Seorang pemimpin harus selalu mengikuti perkembangan dan kemajuan bidang kerjanya agar mampu memenuhi tuntutan masyarakat dan kemajuan teknologi. Disamping itu seorang pemimpin juga 
harus mampu melihat hubungan bidang tugasnya dengan bidang-bidang lain yang mempengaruhinya. Dengan demikian pengetahuannya akan bertambah luas.

o. Sehat jasmani dan rohani. Kesehatan jasmani dan rohani sangat besar pengaruhnya terhadap perwujudan kepemimpinan yang efektif. Yang mana hal tersebut memungkinkan seorang pemimpin mengikuti, mengembangkan dan mengawasi berbagai kegiatan organisasi dan orang-orang yang dipimpinnya secara tepat, cepat dan bijaksana.

Sedangkan menurut Burhanuddin, syarat-syarat kepribadian yang harus dimiliki oleh seorang pemimpin adalah:

a. Personality, yang mana melalui sifat-sifat kepribadian tersebut, seseorang dapat memperoleh pengakuan dari orang lain sekaligus menjadi penentu bagi kepemimpinannya.

b. Purposes, yaitu seorang Kepala Madrasah harus benar-benar memahami tujuan pendidikan itu sendiri secara jelas.

c. Knowledge, yaitu suatu kelompok akan menaruh kepercayaan pada sang pemimpin, apabila mereka menyadari bahwa otoritas kepemimpinannya dilengkapi dengan skop pengetahuan yang luas dan mampu memberikan keputusan yang mantap.

d. Profesional skill, yaitu Kepala Madrasah harus memiliki ketrampilan-ketrampilan profesional yang efektif dalam fungsi-fungsi administrasi pendidikan.

Bila semua prasyarat kepribadian sebagaimana tersebut di atas dimiliki oleh seorang pemimpin, maka ia akan dapat menjalankan kepemimpinannya dengan baik. Oleh karena itu, setiap pemimpin pendidikan hendaknya berusaha memiliki sifatsifat kepribadian tersebut.

\section{Gambaran Tipologi Sang Pemimpin Sosial}

Dalam menjalankan tugasnya sebagai pemimpin, yaitu menggerakkan atau memberi motivasi orang lain agar melakukan tindakan-tindakan yang selalu terarah pada pencapaian tujuan organisasi, berbagai cara dapat dilakukan oleh seseorang pemimpin. Cara itu mencerminkan sikap dan

\footnotetext{
${ }^{12}$ Burhanuddin, Analisis Administrasi, h. 78-80.
} 
pandangan pemimpin terhadap orang yang dipimpinnya. Yang memberikan gambaran pula tentang bentuk (tipe) kepemimpinannya yang dijalankannya.

Adapun tipe-tipe kepemimpinan sosial yang pokok itu ada tiga yaitu otokratis, laissez faire, dan demokratis. ${ }^{13}$ Sedangkan menurut Hendyat Soetopo dan Wasty Soemanto, kepemimpinan pendidikan dapat diklasifikasikan menjadi 4 tipe kepemimpinan yaitu: (1) Tipe Otoriter/Otokrasi; (2) Tipe Laissez faire; (3) Tipe Demokratis; dan (4) Tipe Pseudo Demokratis. $^{14}$

Untuk lebih jelasnya, penulis akan diuraikan masingmasing dari tipe kepemimpinan tersebut.

1) Tipe Otokratis

Otokratis berasal dari kata oto yang berarti sendiri, dan kratos yang berarti pemerintah. Jadi otokratis berarti mempunyai sifat memerintah dan menentukan sendiri. ${ }^{15}$

Adapun ciri-ciri dari pemimpin otokratis itu antara lain:

a. Menganggap organisasi sebagai pemilik pribadi.

b. Mengidentikkan tujuan pribadi dengan tujuan organisasi.

c. Menganggap bawahan sebagai alat semata mata.

d. Tidak mau menerima kritik, saran, dan pendapat.

e. Terlalu tergantung pada kekuasaan formalnya.

f. Dalam tindakan penggerakannya sering mempergunakan approach yang mengandung unsur paksaan dan punitif (bersifat menghukum).

Akibat dari kepemimpinannya tersebut, guru menjadi orang yang penurut dan tidak mampu berinisiatif serta takut untuk mengambil keputusan, guru dan murid dipaksa bekerja keras dengan diliputi perasaan takut akan ancaman hukuman, serta sekolah akan menjadi statis.

2) Tipe Laissez faire

13 M. Ngalim Purwanto dan Sutadji Djojopranoto, Administrasi Pendidikan, (Jakarta: Mutiara Sumber Widya, 1991), h. 46.

${ }^{14}$ Hendyat Soetopo dan Wasty Soemanto, Kepemimpinan dan Supervisi, h. 284.

15 M. Moh. Rifai, Administrasi Pendidikan, (Bandung: jemmars, 1986), h. 38 . 
Laissez faire jika diterjemahkan dapat diartikan sebagai "biarkan saja berjalan" atau 'tidak usah dihiraukan', jadi mengandung sikap 'masa bodo'. ${ }^{16}$ Bentuk kepemimpinan ini merupakan kebalikan dari bentuk kepemimpinan otoriter. Kepemimpinan ini pada dasarnya tidak melaksanakan kegiatan dengan cara apapun. Pemimpin berkedudukan sebagai simbol dan tidak pernah memberikan kontrol dan koreksi terhadap pekerjaan anggota-anggotanya. Pembagian tugas dan kerjasama diserahkan kepada anggota-anggota kelompoknya tanpa petunjuk atau saran-saran dari pemimpin, sehingga kekuasaan dan tanggungjawab menjadi simpang siur dan tidak terarah.

Kepemimpinan seperti ini pada dasarnya kurang tepat bila dilaksanakan secara murni di lingkungan lembaga pendidikan. Karena dalam hal ini setiap anggota kelompok bergerak sendiri-sendiri sehingga semua aspek manajemen administratif tidak dapat diwujudkan dan dikembangkan.

\section{3). Tipe Demokratis}

Kepemimpinan demokratis adalah kepemimpinan yang aktif, dinamis, dan terarah yang berusaha memanfaatkan setiap orang untuk kepentingan kemajuan dan perkembangan organisasi. Saran-saran, pendapat-pendapat dan kritik-kritik setiap anggota disalurkan dengan sebaik-baiknya dan diusahakan memanfaatkannya bagi pertumbuhan dan kemajuan organisasi sebagai perwujudan tanggung jawab bersama.

Hal ini menunjukkan bahwa di dalam musawarah silang pendapat selalu terbuka. Apalagi jika orang-orang yang terlibat terdiri dari banyak orang. Oleh sebab itu kita dianjurkan untuk bersikap tenang dan hati-hati yaitu dengan memperhatikan setiap pendapat, kemudian mentarjihkan suatu pendapat dengan pendapat lain yang lebih banyak maslahat dan faidahnya bagi kepentingan bersama dengan segala kemampuan yang ada.

\section{4). Tipe Pseudo Demokatis}

Pseudo berarti palsu, pura-pura. Pemimpin semacam ini berusaha memberikan kesan dalam penampilannya seolah-olah dia demokratis, sedangkan maksudnya adalah otokrasi,

\footnotetext{
${ }^{16}$ Ibid, h. 41 .
} 
mendesakkan keinginannya secara halus. ${ }^{17}$ Jadi, pemimpin pseudo demokratis sebenarnya adalah orang otokratis, tetapi pandai menutup-nutupi sifatnya dengan penampilan yang memberikan kesan seolah-olah ia demokratis.

Sedangkan menurut Sondang P. Siagian, tipe pemimpin itu dapat digolongkan menjadi lima, yaitu: (1) Tipe Otokrasi, (2) Tipe Militeristis, yaitu senang pada formalitas yang berlebihlebihan, menuntut disiplin yang tinggi dan kaku dari bawahan serta sukar untuk menerima kritikan, (3) Tipe Paternalistik, yaitu pemimpin bersikap terlalu melindungi, jarang memberikan kesempatan kepada bawahan untuk mengambil inisiatif dan mengambil keputusan serta bersikap maha tahu; (4) Tipe Kharismatik, yaitu pemimpin yang diterima karena kepribadiannya yang berpengaruh dan dipercayai sehingga diikuti pendapat dan keputusannya; dan (5) Tipe Demokratis, secara implisit tergambar bahwa untuk menjadi pemimpin tipe demokratis bukanlah suatu hal yang mudah untuk dicapai. Akan tetapi karena pemimpin yang demikianlah yang paling ideal, alangkah baiknya jika semua pemimpin berusaha menjadi seorang pemimpin yang demokratis. ${ }^{18}$

\section{Bebarapa Faktor yang Mempengaruhi Kepemimpinan Sosial}

Dalam menjalankan tugas kepemimpinannya, seseorang yang menduduki profesi sebagai pemimpin sosial, sedikitnya dipengaruhi oleh faktor-faktor yang mewarnai pola kepemimpinannya. Hal ini sebagaimana yang dikemukakan oleh Hendyat Soetopo dan Wasty Soemanto, sebagai berikut: (1) Faktor-faktor legal yang berpengaruh dalam kependidikan individu masa lalu; (2) Kondisi sosial ekonomi dan konsepkonsep pendidikan masa lalu sebagai pengaruh dalam kepemimpinan; (3) Hakekat dan atau ciri sekolah sebagai pengaruh kepemimpinan; (4) Kepribadian pemimpin dan latihan-latihan sebagai faktor yang mempengaruhi kepemimpinan; (5) Perubahan-perubahan yang terjadi dalam

${ }^{17}$ M. Moh. Rifai, Administrasi Pendidikan, h. 39.

18 Sondang P. Siagian, Filsafat Administrasi, (Jakarta: CV Haji Masagung, 1989), h. 41. 
perkembangan pribadinya sebagai faktor yang mempengaruhi kepemimpinan. ${ }^{19}$ Di samping itu pula, M. Ngalim Purwanto juga mengemukakan adanya faktor-faktor yang pada umumnya sangat dominan mempengaruhi perilaku seorang pemimpin, di antaranya: (1) Keahlian dan kemampuan yang dimiliki oleh pemimpin untuk menjalankan kepemimpinannya; (2) Jenis pekerjaan atau lembaga tempat pemimpin itu melaksakan tugas jabatannya; (3) Sifat-sifat kepribadian pemimpin; (4) Sifat-sifat kepribadian pengikut atau kelompok yang dipimpinnya; dan (5) Sangsi-sangsi yang ada di tangan pemimpin. ${ }^{20}$

Untuk lebih jelasnya, akan penulis uraikan satu-persatu mengenai faktor-faktor yang mempengaruhi kepemimpinan, sebagai berikut:

1. Keahlian dan Pengetahuan yang dimiliki oleh pemimpin untuk menjalankan kepemimpinannya. Yang termasuk dalam hal ini adalah latar belakang pendidikan atau ijazah yang dimiliki, apakah sudah sesuai dengan tugas-tugas kepemimpinan yang menjadi tanggung jawabnya; pengalaman kerja sebagai pemimpin, apakah sudah mendorong dia untuk berusaha memperbaiki dan mengembangkan kecakapan dan ketrampilannya dalam memimpin. Seorang pemimpin yang ideal tidak akan merasa puas hanya dengan mengandalkan latar belakang pandidikan dan pengalamannya saja, tanpa selalu berusaha mengembangkan diri dengan menambah pengetahuan.

2. Jenis pekerjaan atau lembaga tempat pemimpin itu melaksanakan tugas jabatannya. Tiap organisasi atau lembaga yang tidak sejenis memiliki tujuan yang berbeda dan menuntut cara-cara pencapaian tujuan yang tidak sama. Seorang yang sedang memimpin anak buah dalam kapal yang sedang tenggelam, tidak akan sama dengan perilaku dan sikap seorang guru yang sedang memimpin diskusi dalam kelas. Oleh karena itu, tiap jenis lembaga

\footnotetext{
${ }^{19}$ Hendyat Soetopo dan Wasty Soemanto, Kepemimpinan dan Supervisi, h. 16.

${ }^{20}$ M. Ngalim Purwanto, Administrasi dan Supervisi Pendidikan, (Bandung: RemajaRosda Karya, 1993), h.59.
} 
memerlukan perilaku dan sikap kepemimpinan yang berbeda pula.

3. Sifat-sifat kepribadian pemimpin. Secara psikologis, manusia mempunyai sifat, watak dan kepribadian yang berbeda-beda. Ada yang selalu dapat bersikap dan bertindak keras dan tegas, tetapi adapula yang lemah dan kurang berani. Dengan adanya perbedaan-perbedaan yang dimiliki oleh masing-masing pemimpin, meskipun beberapa dari mereka memiliki latar belakang pendidikan sama dan diserahi tugas memimpin lembaga yang sejenis, tetapi karena adanya perbedaan kepribadian diantara mereka, maka akan timbul pula perilaku dan sikap yang berbeda dalam menjalankan kepemimpinannya.

4. Sifat-sifat kepribadian pengikut atau kelompok yang dipimpinnya. Perbedaan sifat-sifat individu dan sifat-sifat kelompok sebagai anak buah atau pengikut seorang pemimpin akan mempengaruhi bagaimana seyogyanya perilaku dan sikap pemimpin itu dalam menjalankan kepemimpinannya. Tentang sifat-sifat kepengikutan, $\mathbf{M}$. Ngalim Purwanto mengemukakan ada lima macam kepengikutan, yaitu:

a. Kepengikutan karena naluri dan nafsu.

b. Kepengikutan karena tradisi dan adat.

c. Kepengikutan karena agama dan budi nurani.

d. Kepengikutan karena peraturan hukum. ${ }^{21}$

Agar para anggota kelompok dapat mematuhi dan mentaati perintah serta menjalankan tugasnya dengan ikhlas dan sabar serta tidak merasa tertekan, maka sangat penting bagi seorang pemimpin dalam menjalankan kepemimpinannya untuk mengetahui dan mempelajari sifat atau tipe kepengikutannya yang ada pada anggota kelompoknya.

5. Sangsi-sangsi yang ada di tangan pemimpin.Kekuatankekuatan yang ada dibelakang pemimpin menentukan sikap dan tingkah lakunya. Sikap atau reaksi anggota kelompok dari seorang pemimpin yang mempunyai wewenang penuh akan lain jika dibandingkan dengan seorang pemimpin yang kurang atau tidak berwenang. Seorang guru yang baru

\footnotetext{
${ }^{21}$ Ibid, h. 60.
} 
dibentuk sebagai pejabat pimpinan Madrasah akan bertindak dan berperilaku lain dengan seorang Kepala Madrasah yang telah resmi diangkat dengan surat keputusan dari atasan. Hal ini dapat dikatakan bahwa tinggi rendahnya tingkat kekuasaan dan atau perangkat perundang-undangan menentukan tinggi rendahnya kekuatan atau sangsi seorang pemimpin yang diangkat oleh penguasa atau berdasarkan perundangan tersebut.

\section{Kesimpulan}

Dari uraian di atas dapat disimpulkan bahwasanya betapa sangat berpengaruh latar belakang pendidikan seseorang dalam menjalankan pola kepemimpnanya termasuk di antaranya faktor pengaruh perkembangan pola interaksi serta sifat bawaan yang dimilikinya. Wallahu a'lam.

\section{Daftar Pustaka}

Abu Ahmadi, Nur Uhbiyati, Ilmu Pendidikan, Jakarta: Rineka Cipta, 1991.

Burhanuddin, Analisis Administrasi Manajemen dan

Kepemimpinan Pendidikan, (Jakarta: Bumi Aksara, 1994 Djumberansyah, Indar, Filsafat Pendidikan, Surabaya:

Abditama, 1994

Dirawat, Busro Lamberi, Soekarto Indra Fachrudi, Pengantar

Kepemimpinan Pendidikan, Surabaya: Usaha Nasional, 1983

Nawawi, Hadari, Administrasi Pandidikan, Jakarta: CV Haji Masagung, 1998

Purwanto, M. Ngalim, dan Sutadji Djojopranoto, Administrasi

Pendidikan, Jakarta: Mutiara Sumber Widya, 1991

Purwanto, M. Ngalim, Administrasi dan Supervisi Pendidikan, Bandung: RemajaRosda Karya, 1993

Rifai, M. Moh. Administrasi Pendidikan, Bandung: jemmars, 1986

Soetopo, Hendyat, dan Wasty Soemanto, Kepemimpinan dan

Supervisi Pendidikan, Jakarta: Bina Aksara, 1984 
Kepemimpinan Sosial, Oleh: Imam Taulabi

Siagian, Sondang P. Filsafat Administrasi, Jakarta: CV Haji Masagung, 1989

Zuhairini et.al, Metodologi Pendidikan Agama Islam, Solo:

Ramadhani, 1983 